

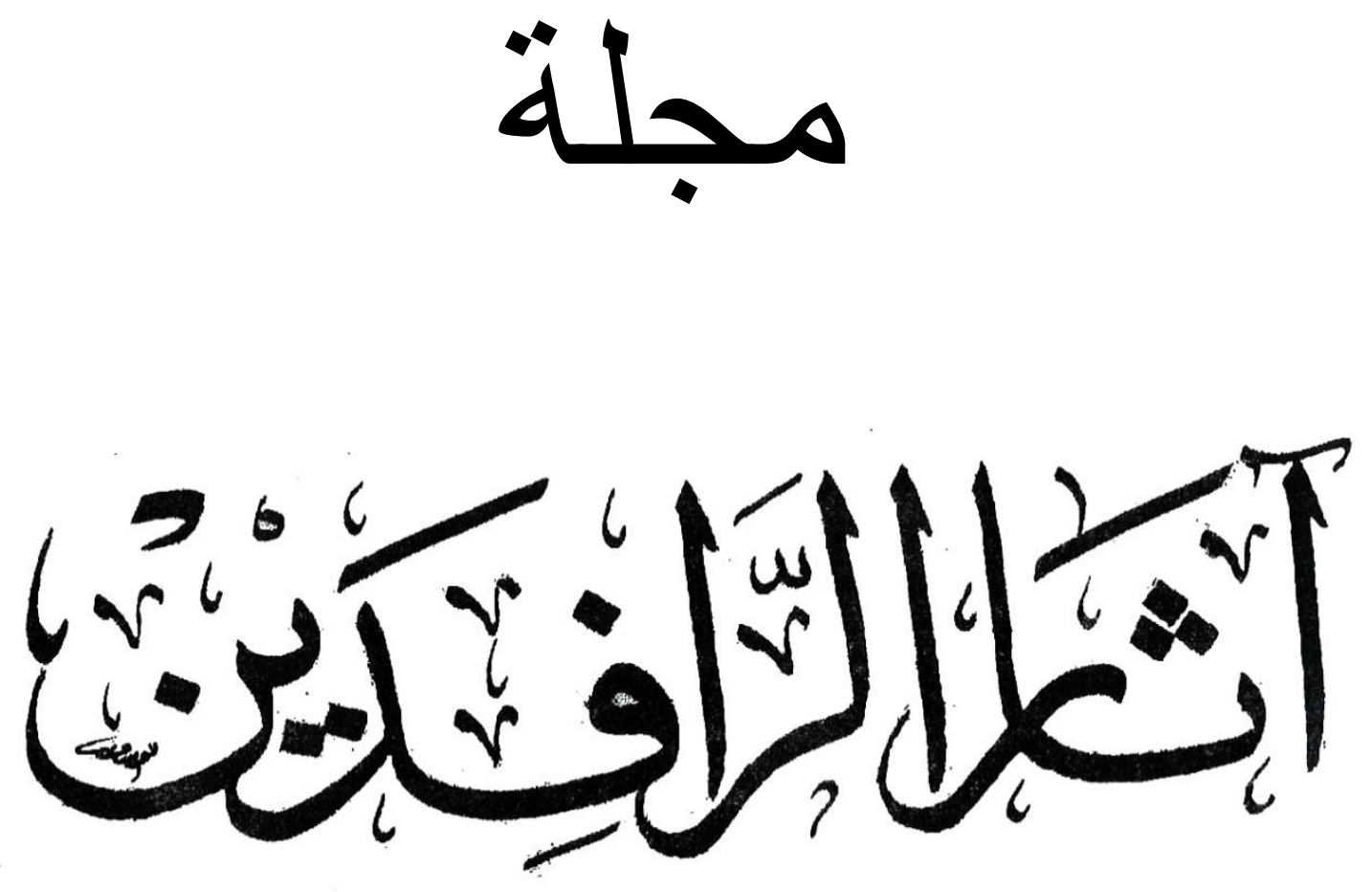

هجلة علمية همكمة تبحث في آثار العراق و الشرق الأدنى القديم تصدر عن كلية الآثار في جاهعة الموصل

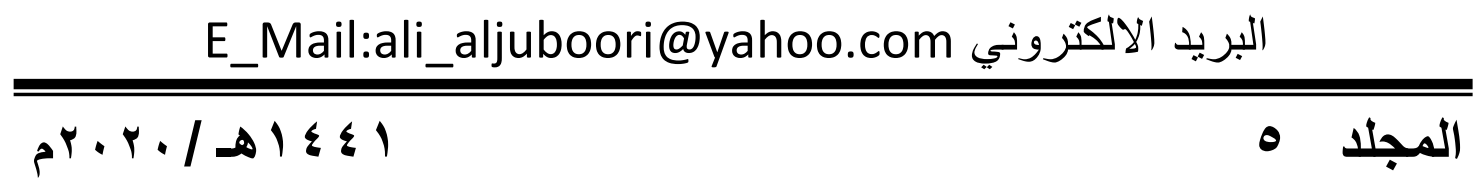



رقم الإِيداع في دار الكتب و الوثائق ببغداد

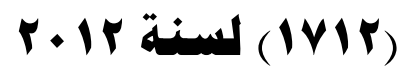





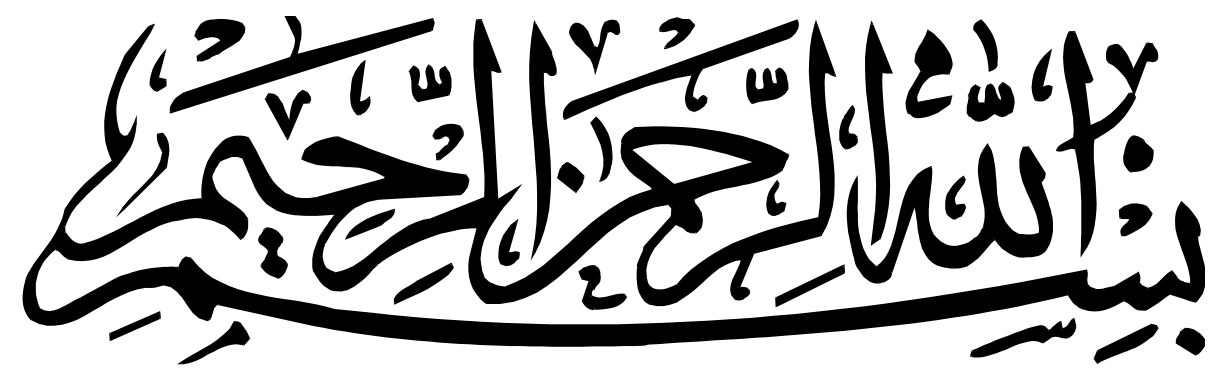





$$
\text { أ.د. علي ياسية التمرير الجبوري }
$$

$$
\begin{aligned}
& \text { أ.م.د. فيان هوفق رشيد النعيمي } \\
& \text { أ.د. صفوان ساهي سعيد الرفاعي } \\
& \text { سكرتير التصرير } \\
& \text { نائب رئيس التمرير }
\end{aligned}
$$

الأوضاs

أ.د. شعلان كاهل اسماعيل

أ.د. عاهر عبدالاله نجم الجُميلي

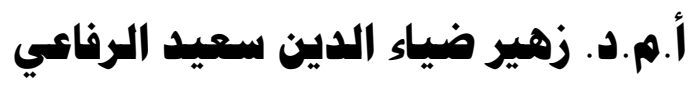

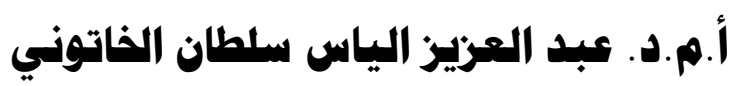

$$
\begin{aligned}
& \text { الخبير الاغوي } \\
& \text { أ.م.د. همن يميى هممد العبادي } \\
& \text { كلية الآداب - جاهعة الموصل } \\
& \text { الهيأة الاستشارية }
\end{aligned}
$$

جامعة الموصل

جاهمة بغداد

جاهعة الموصل

جامعة الموصل

جاهمة الموصل

جاهعة القادسية

جاهعة الكوفة 



\section{قواعد النشر في المبلة}

• يشترط أن يكون البحث ضهن الاختصاصات التي تُعنى بها المجلة • يشترط على الباحث الالتزام بالموضوعية و المنهج العلمي في البحث و التحليل ،و أن يلتزه بشروط البحث العلمي هن حيث التبويب و استعمال الهواهش و الإشارة إلى المصادر و المراجع وفق طريقة هنهجية و احدة ،و في

$$
\text { آخر البحث }
$$

• يشترط على الباحث هراعاة الجوانب الشكلية و الاهتهام بسلاهة لغة البحث هن الأخطاء اللغوية و المطبعية

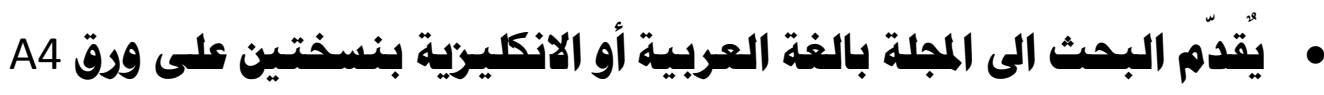
• يرافق البحث في أوله هلخص" باللغة الانكليزية على أن لا يريد عدد كلماته

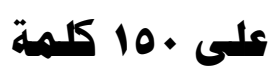

• يشترط أن لا يكون البحث قد نشر او قبل للنشر في أيّة دورية علمية داخل

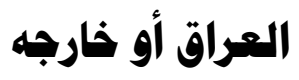

• يشترط على الباحث أن لا تتجاوز عدد صفحات بثه عن ro صفحة • يشترط في البحث أن تكون المشاهد و الأشكال الفنية المرافقة له عالية الجودة • أصول البحث المقدهة إلى البلة لا ترد أو تُسترجع سواء نشرت أم لم تنشر • تعتمد المجلة هبدأ التمويل الذاتي وتهدد أجور النشر في ضوء الأسعار السائدة 

ثبت المحتويات

\begin{tabular}{|c|c|c|}
\hline 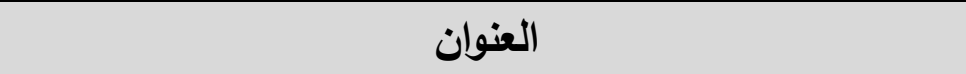 & 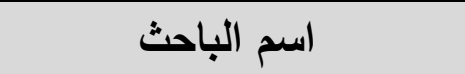 & الصفحة \\
\hline توطئة & أ.د. علي ياسين الجبوري & 1 \\
\hline نعي - الراحل الأستاذ الدكتور عبد القادر عبد الجبار مصطفى & أ.د. جابر خليل إبراهيم & r \\
\hline ملحمة كلكامش : الاصالة والتأثثر & أ.د. علي ياسين الجبوري & $r r-V$ \\
\hline نصوصُّ اقتصاديةٌ غيرُ منشورةٍ مِنْ عَهْرِ الملكِ شو - سين & أ. خالد سالم اسماعيل & 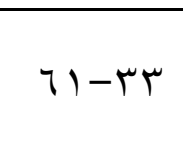 \\
\hline معالجة رُقُقُم طينية من منحف السليمانية & أ. خالد سالم اسماعيل & $V V-7 r$ \\
\hline تسويق المنتجات الزراعية بين مدن العراق القديم & أ.د. حسين ظاهر حمود & $90-\vee 9$ \\
\hline 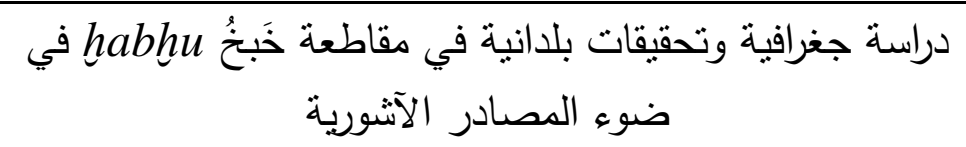 & أ. د. د. عامر عبد الله الجميلي & $1 K V-9 V$ \\
\hline مظاهر الحرية والاستبداد في نظم الإدارة المركزية في المملكة & أ.د. صفوان سامي سعيد & $109-1 Y 9$ \\
\hline شخصية الملوك الآشوريين وصفاتهم القيادية & عفراء يحيى قاسم أ.د. صفوان سامي سعيد & $19 \cdot-171$ \\
\hline تاريخ التتقيبات الأثريّة في مدينة نينوى & د. د. عبد الستار أحمد حسين & Y) $\leq-191$ \\
\hline 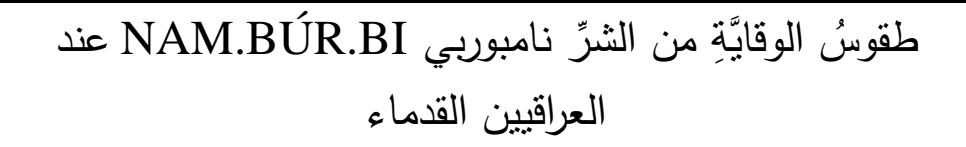 & د. نبيل خالد شيت سليمان & $r Y 9-Y 10$ \\
\hline الزواج بين النص المسماري والقرآني -دراسة مقارنة & أ. م. نسرين أحمد عبد يحيى الجبوري & YTV-rTI \\
\hline عقود قرض غبر منشورة من مدينة لاكابا من العصر البابلي & م. آرام جلال حسن الهموندي & YAN-Yrq \\
\hline الثـــكل والإعجام في الخطّ العربيّ & م. وسن عبد المطلب حسن & $r \cdot V-r \wedge q$ \\
\hline تل الحويش (مدينة أوباسي؟) في الكتابات المسمارية والتحريات & م. غسان صالح الحميضة & $r r \leqslant-r \cdot q$ \\
\hline المواقعُ الجغرافيةُُ لانتشارِ فخارِ العُبيد الثمالي & م.م. دريد سليم بولس & 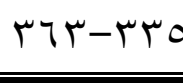 \\
\hline
\end{tabular}





\section{بسم الله الرحمن الرحيم \\ توطئة}

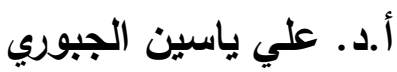

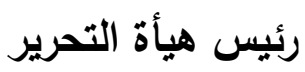

يصدر العدد الخامس من مجلة آثار الرافين الثابع لكلية الآثار - جامعة الموصل

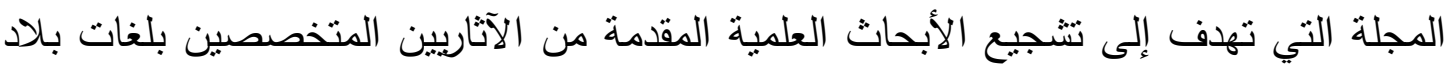

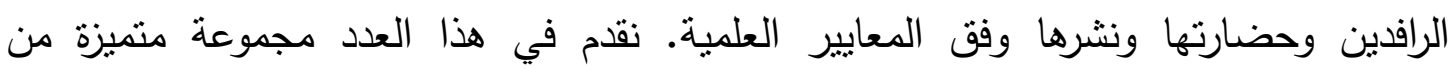

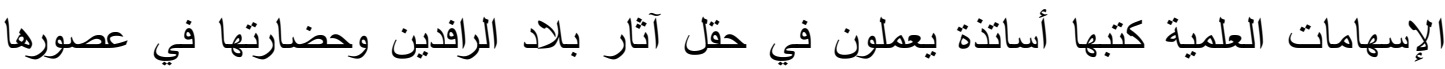

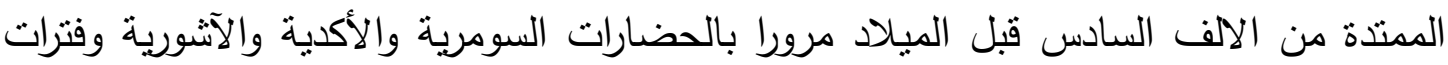

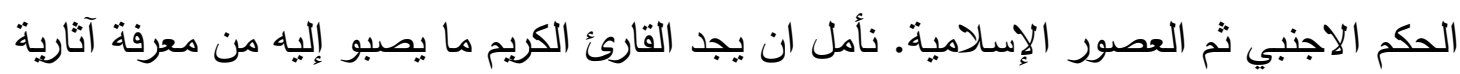

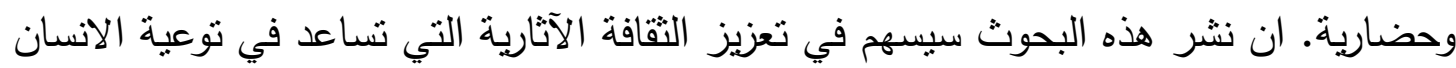

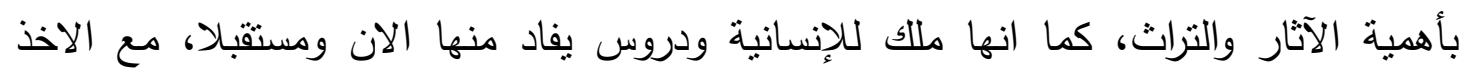

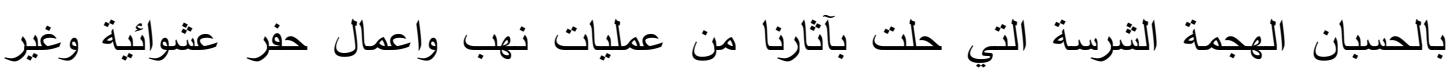

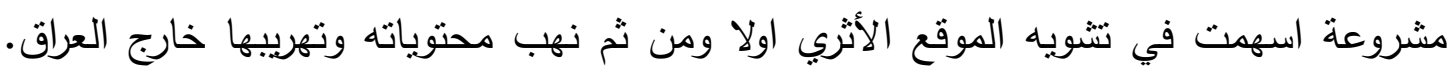

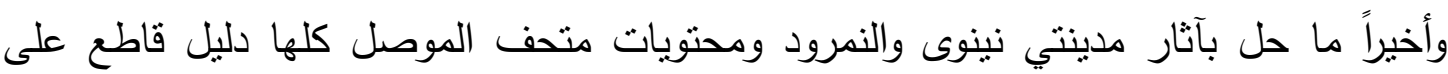

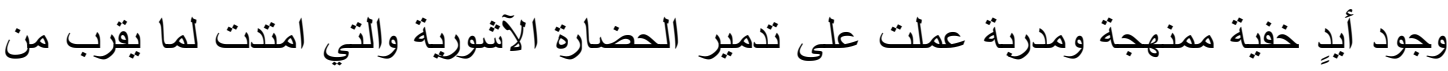
( ب.... T الف سنة قبل الميلاد.

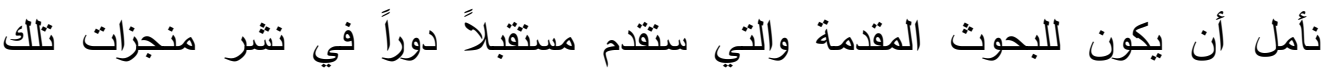

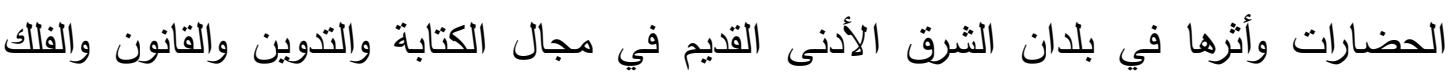
والتجيم والهندسة والرياضيات والطب والآداب بكل مجالاتئها.

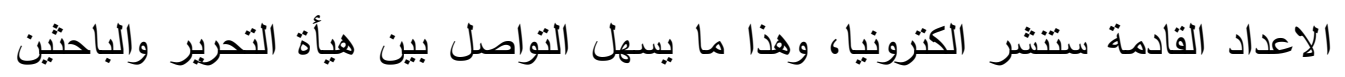
إن شاء الله. وستزود المجلة الباحثين بموقعها الجديد وكيفية التقديم اليها.

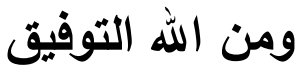





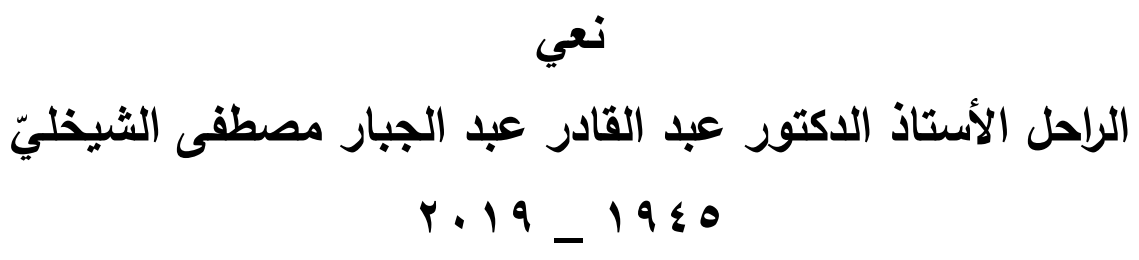

أ.د. - أد جابر خليل إبراهيم

كلية الآثار - جامعة الموصل

رئيس هيأة الآثار والتراث الأسبث

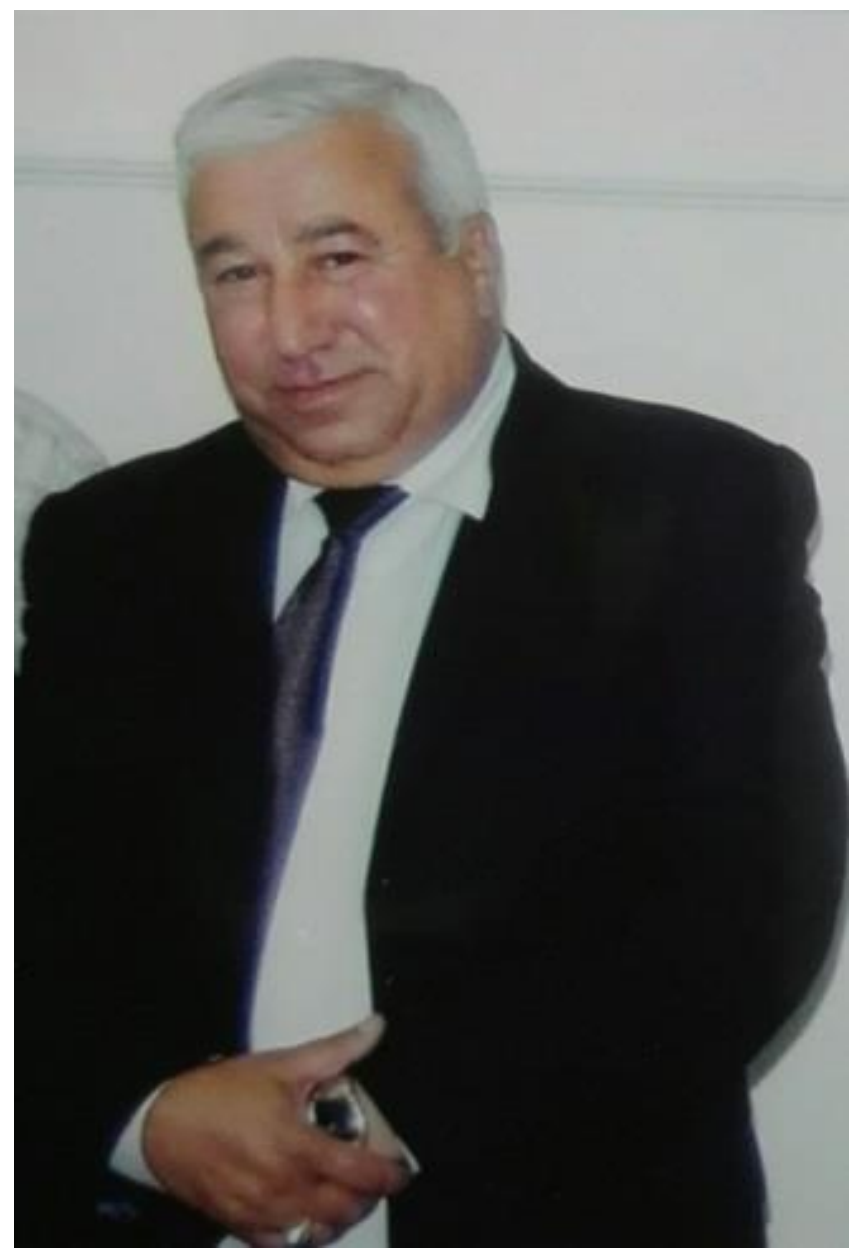

في يوم الجمعة الموافق •r أيلول 19 19 غادر الدكتور عبد القادر مطار بغداد الدولي منوجها الى مدينة اسطنبول بتركيا ، لإجراء فحوصات تتعلق بالقلب في إحدى مشافيها ، برافقه نجله أنس • بعد إجراء الفحوصات الطبية قرر الاطباء المختصين إجراء عملية جراحية كبرى في القلب .

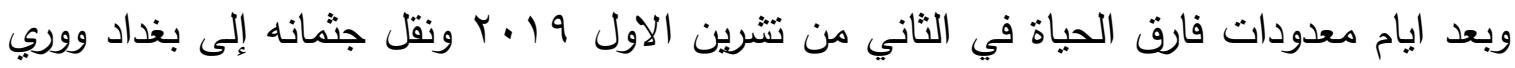

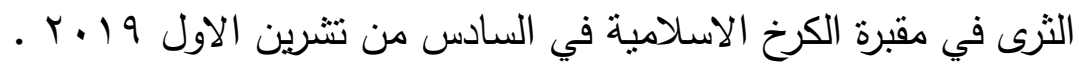


والفقد حالة مؤلمة ، والفراق هاجس مرعب ييقى كامناً في ذهن الإنسان وإن كان تفسيره هو انتقال من حياة زائلة إلى أخرى دائمة مستقرة .

ولد الفقيد عام 19 1 في حي عريق من أحياء مدينة بغداد معروف باسم (باب الثيخ ) نسبة إلى الثيخ الزاهد عبد القادر بن موسى بن عبداله الجيلي (الكيلاني) الذي فيه مرقده ومسجده دئه · الجامع أكمل المرحوم عبدالقادر دراسته الابتدائية والإعدادية في مدارس بغداد ثم التحق بعدها بقسم الآثار في كلية الآداب بجامعة بغداد وحصل على شهادة البكالوريوس في الاثار القديمة ـ وأهلته شهادته

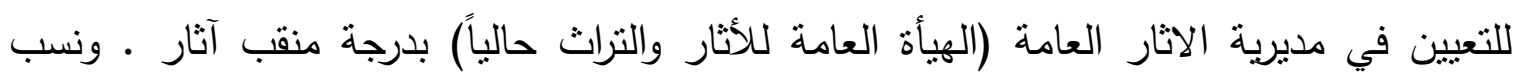
للعمل في دائرة التحريات وحماية المواقع الاثرية ـ والتحق يومئذٍ باللجان التي كانت تعد مؤلفين

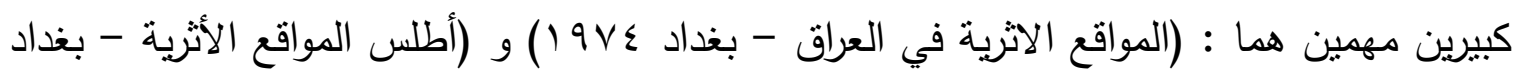

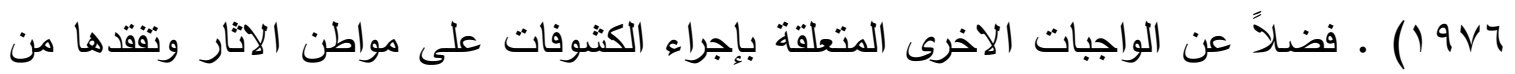
حين لآخر ، من أجل حمايتها من التجاوزات . في بداية شهر آذار من سنة 19 آشحت مديرية الاثار العامة يومها المرحوم عبد القادر

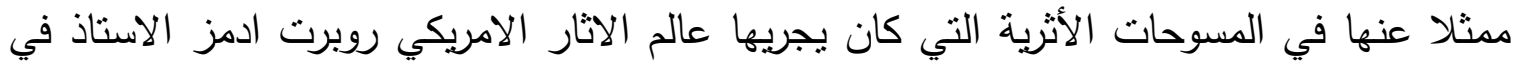

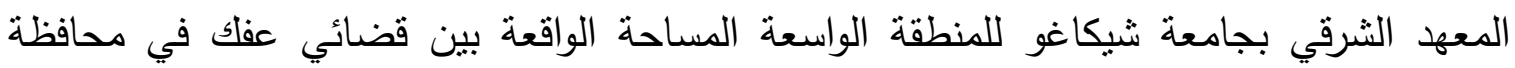

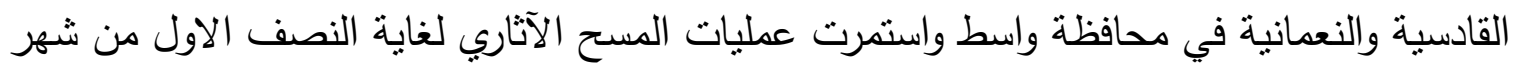
مارس من العام نفسه ـ والهدف من هذه المسوحات هو استكمال الدراسات الخاصة بمجاري الانهار والجداول الدارسة ، والتي كانت تروي المدن والقرى والحقول والبساتين في العصور القديمة ، والتي

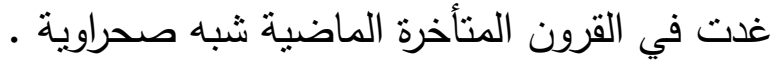
ومن الجدير بالذكر أن الاستاذ ادمز بدأ مشروعه هذا على مراحل ـ كانت الاولى في عام

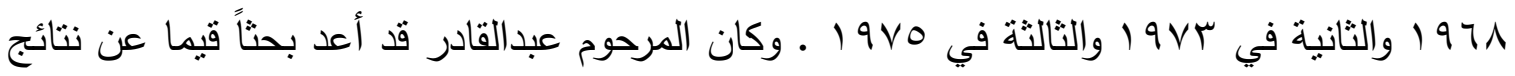

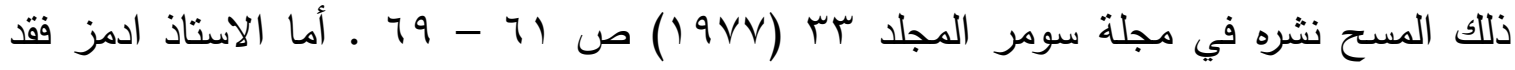
أصدر مؤلفه الثهير (Heartland Cities , Chicago 1981) كانت الأعمال الاثارية هذه علاوة على أعمال المسوحات في منطقة السهل الرسوبي ، قد أكسبت الفقيد مهارة في التحري والتتقيب التي

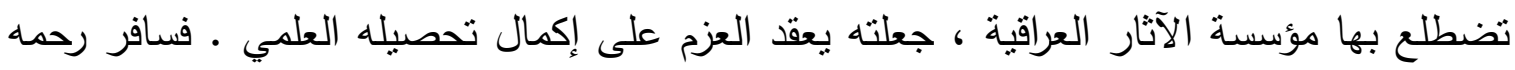

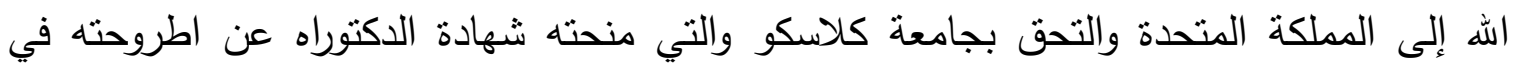


النصوص المسمارية المكتشفة في تليين مشهورين بحوض سهل حمرين هما (السيب وحداد) الواقعين

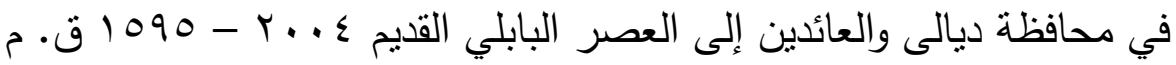

\section{The Old Babylonian Tablets From ME - TURAN (Tell AL SIB and Tell} HADAD) Univiersity of Glasgow June 1983

عاد الدكتور عبدالقادر إلى العراق والتحق بمؤسسة الآثار التي منحته اجازة دراسية لإكمال

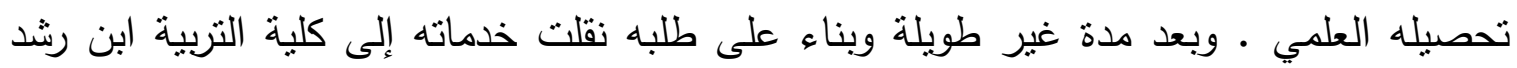
بجامعة بغداد لتدريس تاريخ العراق والوطن العربي في العصور القديمة إلا انه لم ينقطع عن دائرة الآثار والمتحف العراقي وفي الوقت نفسه كانت صلاته العلمية مع قسم الآثار بكلية الآداب في

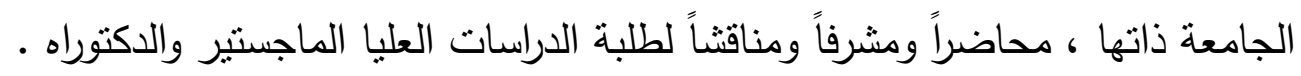
لم يقتصر نشاطه العلمي على كليته بل كان يلبي دعوات الجامعات العراقية لمناقتشة أطاريح

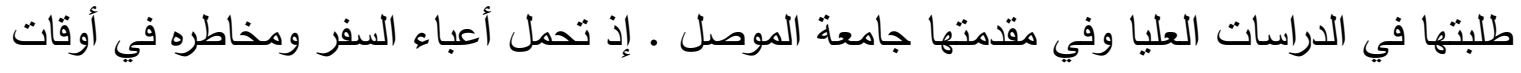

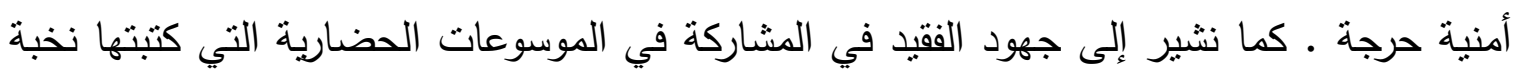

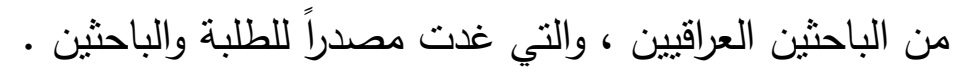

وفضلاً عن ذللك فقد تخرج على يدي الفقيد العديد من الآثاريين والمؤرخين في العراق فأصبح

بعض تلاميذه يقودون العملية التربوية في المدارس والجامعات العراقية .

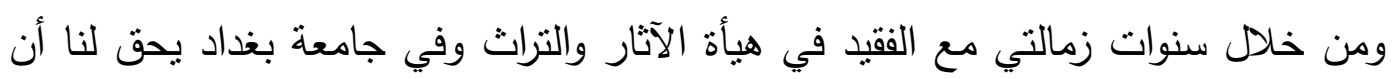

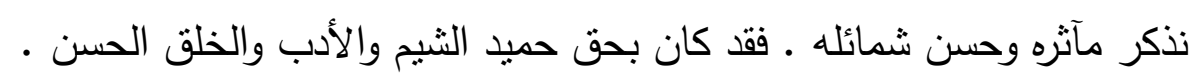

غادرنا المرحوم الدكتور عبدالقادر إلى عالم الآخرة وترك عند عند عائلئنه وزملائه وأصدقائه ومعارفه ومحبيه لوعة الحزن وألم الفراق ـ ندعو الله تعالى أن يتغده بواسع رحمته ، وأن يسكنه

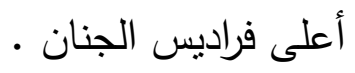

وإنا لله وإنا إليه راجعون 



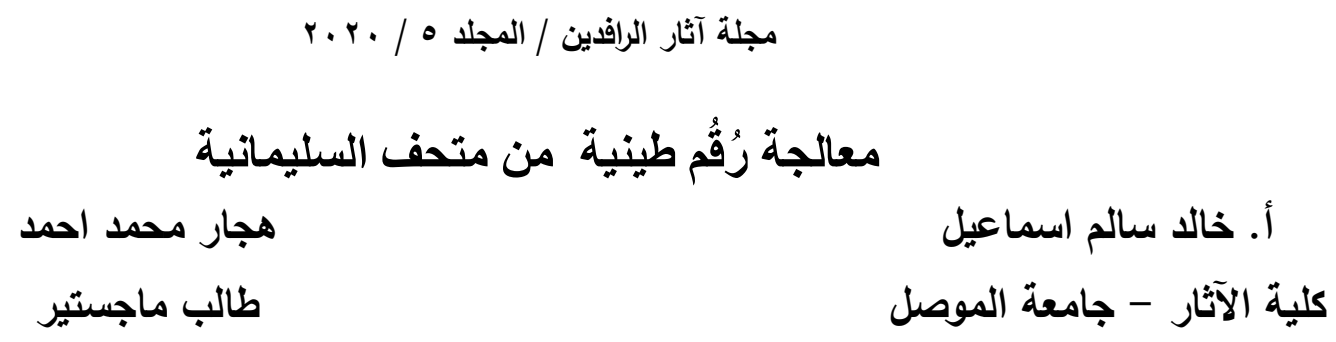

\title{
The Conservation of Clay Tablets from Al-Sulaymaniyah Museum
}

\author{
Prof . Khalid Salim Ismael
}

\author{
Hagar Mohammad Ahmed \\ M.A. student
}

\begin{abstract}
The conservation and cleaning of the clay Tablets have the same importance of historical content . Clay tablets vary in their volumes and shapes; some of them are small and some are big others are very big; whereas their shape is either rectangle or square. Since the clay tablets were made of clay which contains different kinds of salt which were formed as a result of temperature change and high or low humidity; therefore, there are two kinds of clay tablets found in the archaeological sites ,they enter the lab for conservation and cleaning.The first kind is unbaked which were dried under the sun. The second kind is the basically baked or fund in a burned archaeological site. This article shows the stages of the conservation of the clay tablets from the moment of finding it until finishing the conservation, in order to be presented in the museum or to the researchers in a clear and clean way to be studied easily.
\end{abstract}

المقدمة

إنّ اهية تتظيف الرقم الطينية وصيانتها تحظى بالأهية نفسها التي يحتلها محتواها

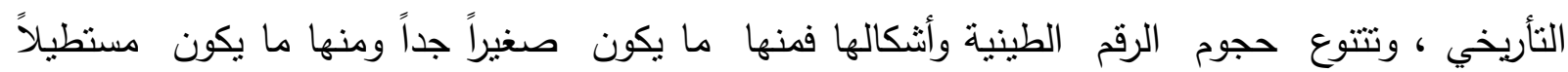

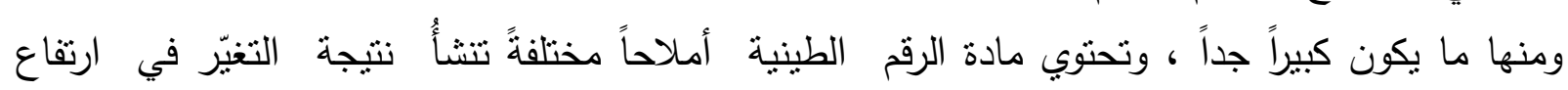

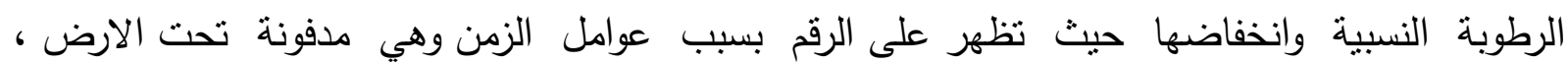

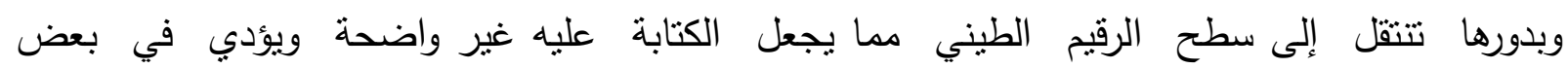

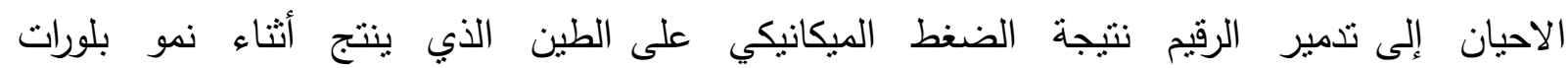

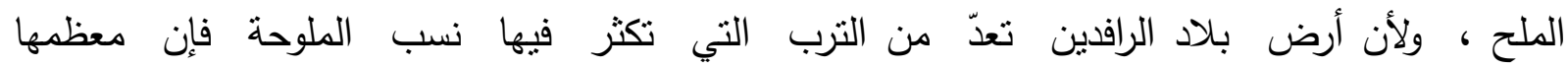

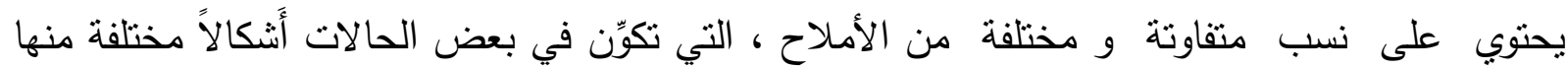

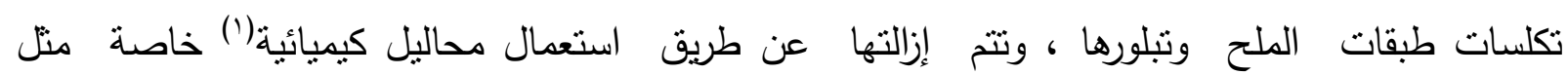


محلول الأسينتون(r) ومحاليل كحولية (r) لإذابتها دون حدوث أَضرار أو تلف في الرقم ، كونها مواد طيارة

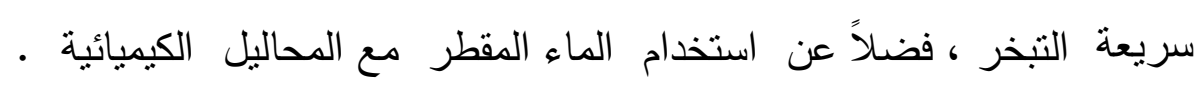

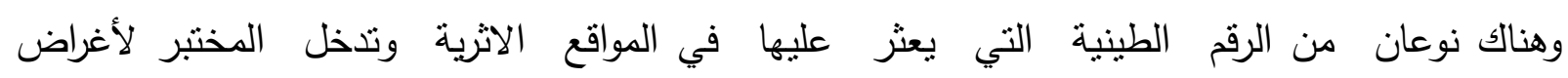

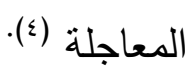

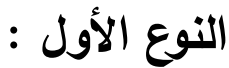

الرقم الطينية غير المشوية :هي رُقُم تمّ تجفيفها تحت أنثعة الثمس (sun dried clay) وتكون

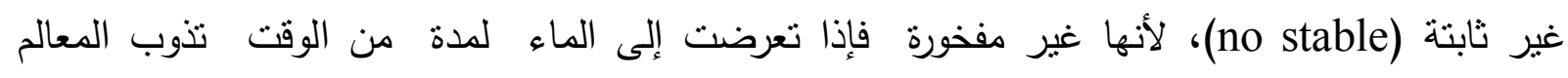

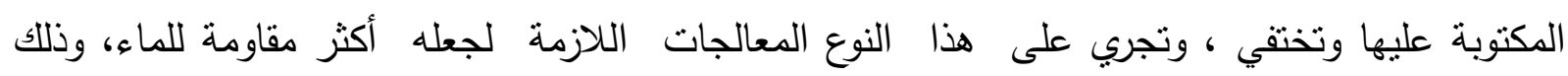

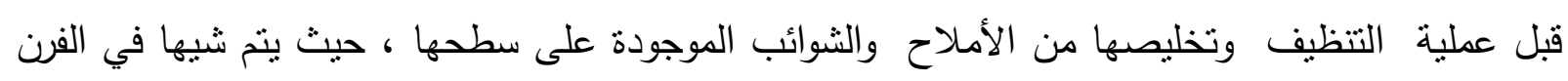

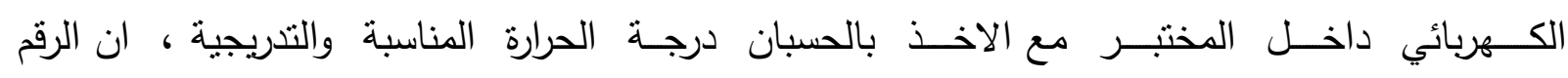

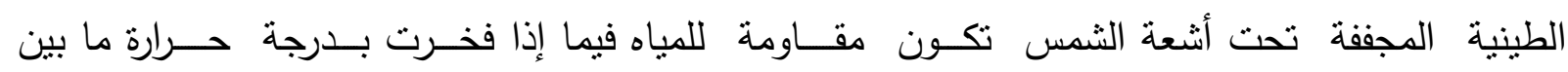

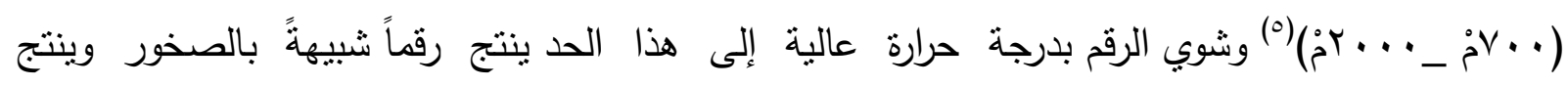

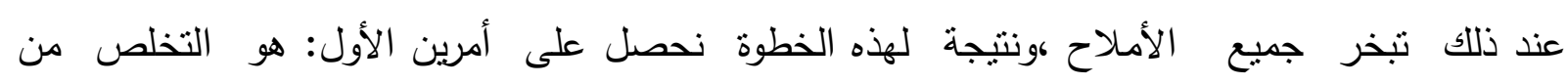

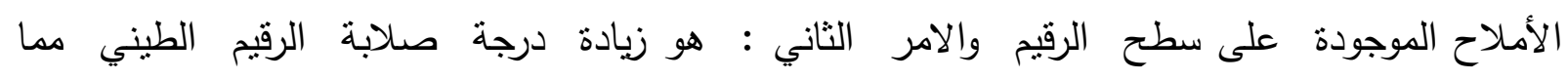

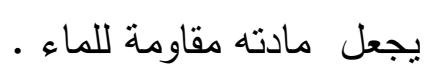
النوع الثاني : التوله الرقم المفخورة (المشوية ) : الرقم المفخورة (المشوية ) أَساساً أو التي فخرت لأسباب ت تنعلق

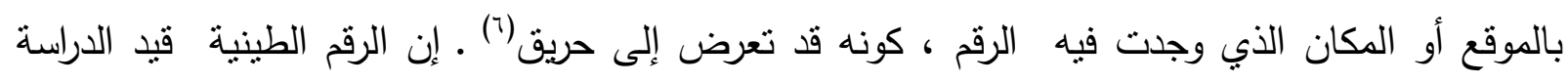

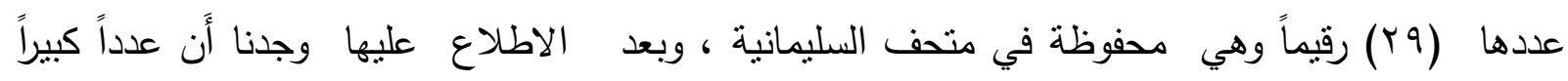

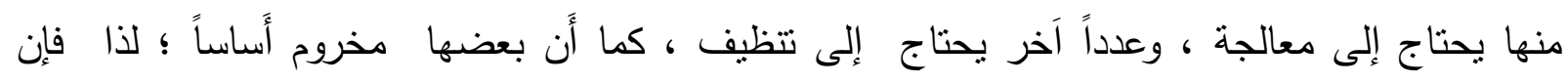

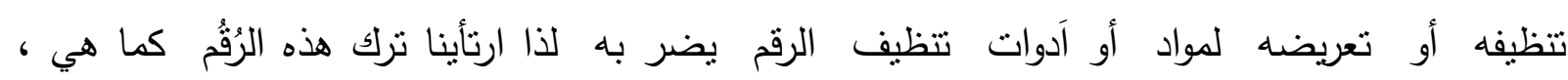

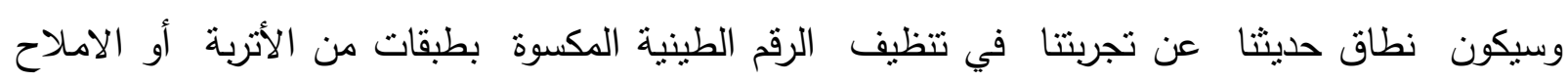

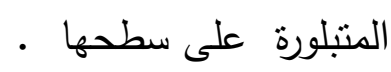
ولنا أن نبدأ بالنص المرقم (SM.4644) :

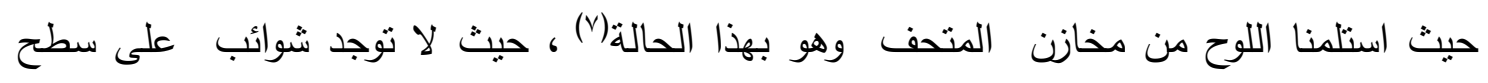

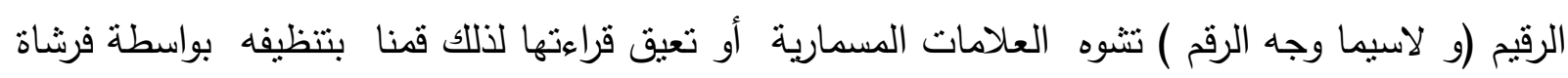


أ. - الا سالم اسماعيل

معالجة رُقُم طينية من متحف السليمانية

\section{هجار محمد احمد - طالب ماجستير}

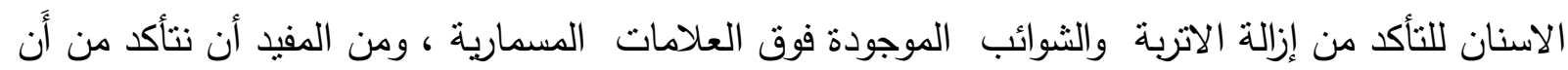

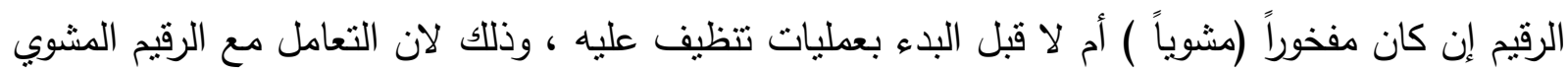

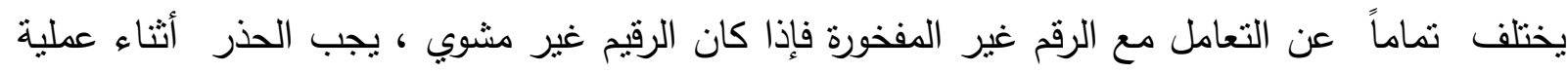
التنظيف وعلينا التعامل مع الرقم غير المشوية باستعمال الفرشاة فقط ويجب اختيارها من النوعيات اللينة

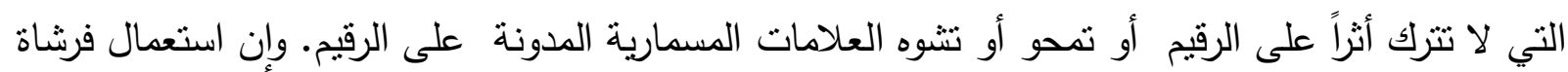

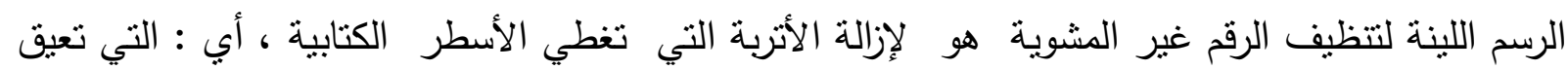

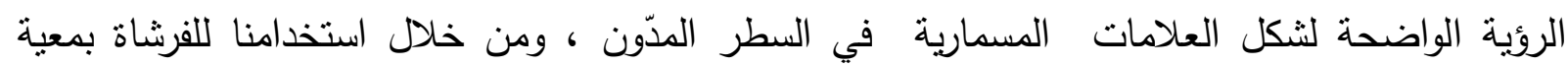

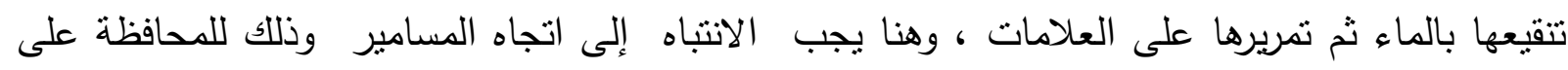

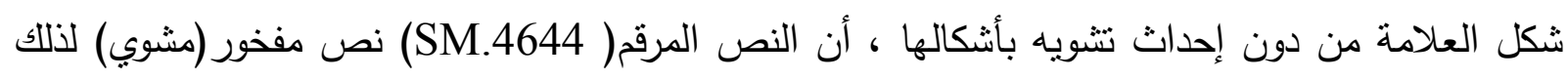

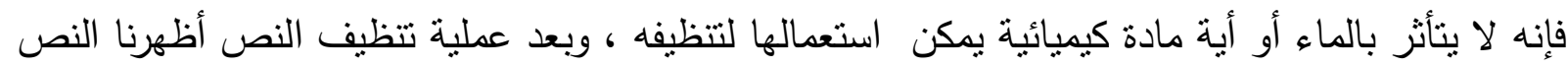

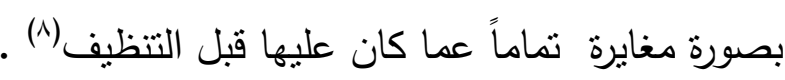

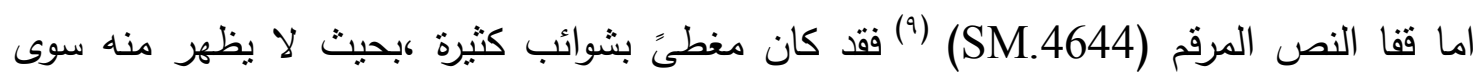

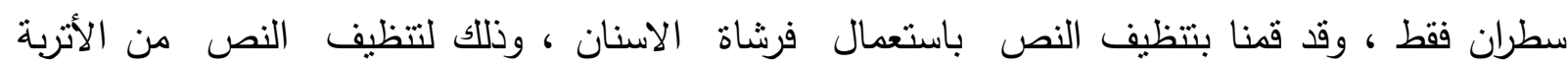

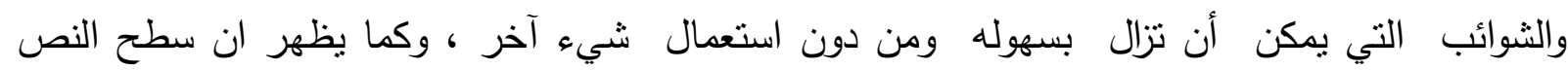

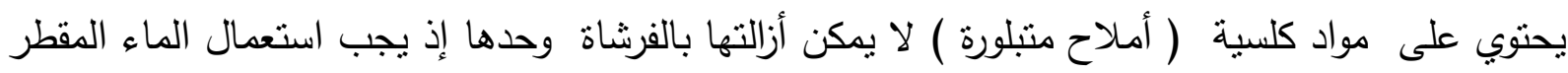

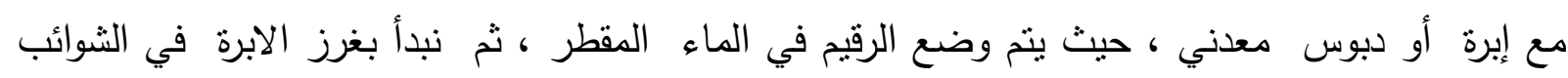

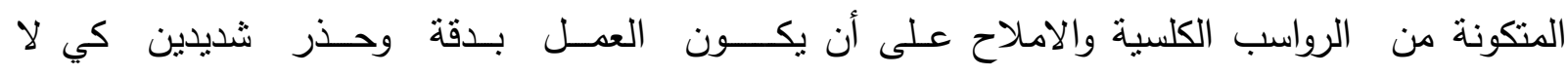

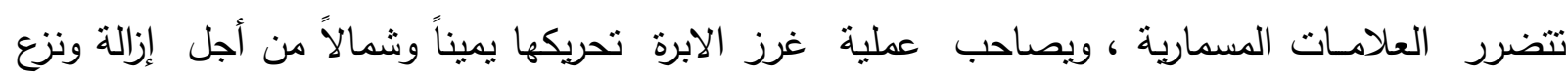

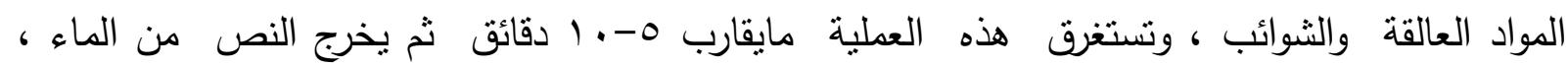

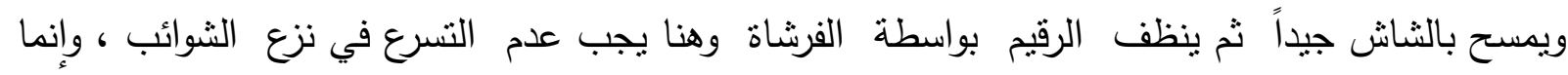

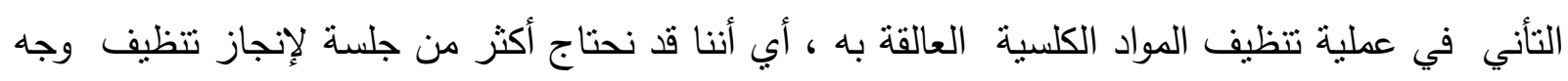

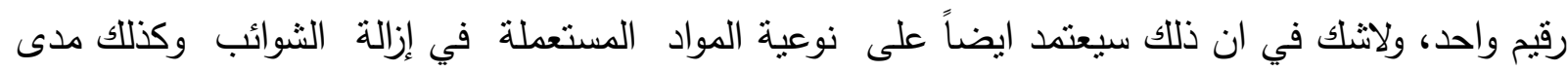

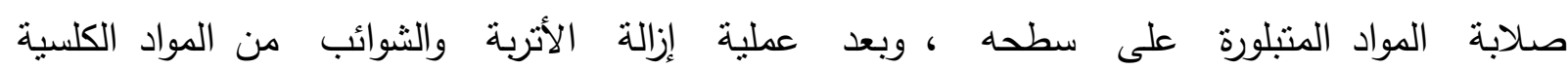

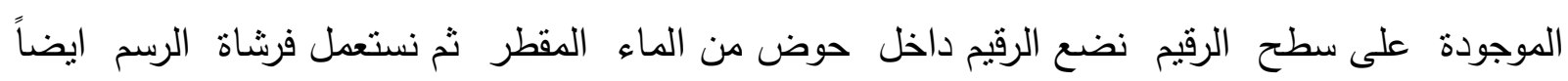

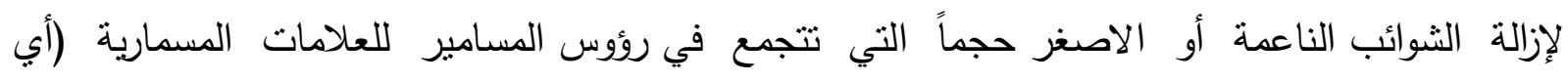

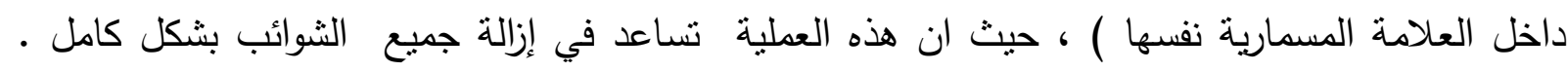

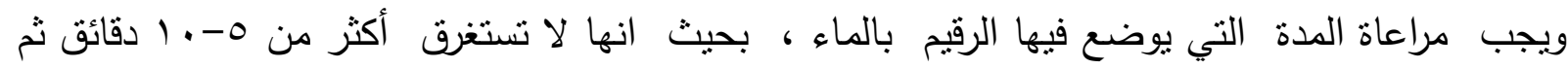




\section{r.r. مجلة آثار الراقدين / المجلد • P}

بعد ذلك يتم تجفيف الرقيم بشكل جيد والتأكد من عدم بقاء أية رطوبة عليه ، إن عملية تتقيع وتجفيف الرقيم وتتظيفه تأخذ وقتاً لذلك يجب الحرص ومراعاة استغلال المدة ما بين العمليتين وكذلك مراعاة

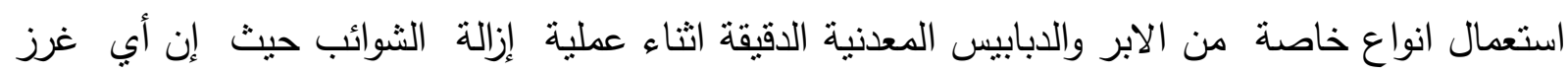
في غير المكان المطلوب إزالته يؤدي إلى تلف جزء من العلامات المسمارية مما يشوه النص الذي إني

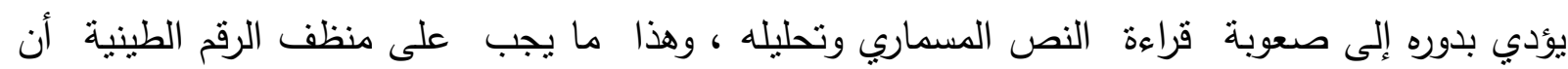
يأخذهُ بالحسبان ، وأن يتعامل مع الرقم بحذر ودقة شديدين ، وكما يظهر النص في الصورة (·') بعد انجاز عملية تتظيفه من الثوائب والاتربة .

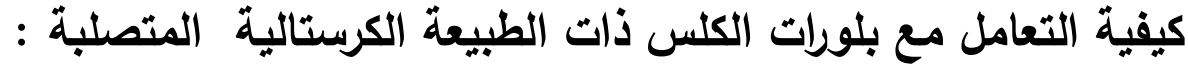

إن تتظيف الرقم الطينية التي يغطي سطحها مواد كلسية منبلورة ذات صلابة (كرستالية)(')، وكما موضح في الثكل الذي أشرنا له أيضاً إذ إن البلورات الكرستالية تشوه الرقم بشكل كامل ، وإن عملية تتظيف هذا النوع من الرقم الطينية يحتاج إلى عناية فائقة ودقه عالية ووقت كافٍ لكي تتم إزالة البلورات الكرستالية من على سطح الرقيم بشكل تام ، و لإنجاز هذه العملية يجب أن نقوم بعدة خطوات تعد مهمة في عملية تتظيف هكذا نوع من الكلس المتبلور : الخطوة الأولى : ألخى نقوم بازالة الأثربة من على سطح الرقيم بواسطة الفرشاة بحيث لا يبقى أَي أَثز للأثربة أو الثوائب عليه .

\section{الخطوة الثانية : n}

نضع الرقيم الطيني داخل كيس من مادة النايلون أو البلاستيك (ذي خاصية قفل وفتح بأحكام ) على ان يكون من الانواع التي لا نتأثز بالمواد الكيميائية التي تنتعمل في عملية تتظيف الرقم الطينية ثم نضع المحلول الكيميائي (rا) بعدها نغلق الكيس ثم يوضع في علبة بلاستيكية ونغلق العلبة بإحكام وذللك لكي لا يكون للهواء أي تأثنر في المحلول الكيميائي ، وينرك مدة من الوقت

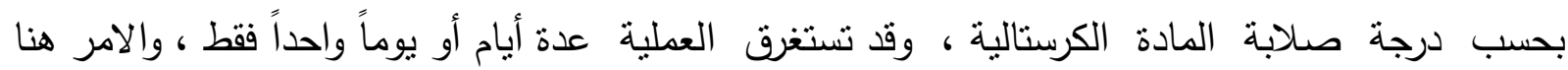
يتوقف على كمية البلورات الموجودة على سطح الرقيم ونوعية الأملاح المتكونة منها البلورات الكرستالية ودرجة صلابتها وفي حالة الرقيم (rا') الذي عملنا على تتظيفهُ حيث تركنا الرقيم في مادة الاسيتون لمدة نصف ساعة ، ثم بعد ذلك قمنا باستخراجه من العلبة البلاسنكية وهيأنا كمية يسيرة من الاسيتون المخفف بالماء المقطر ( الاسيتون المخفف بالماء المقطر ؛ لأن الماء المقطر يقلل من عملية 
أ. خالا سالم اسماعيل

هجار محمد احد - طالب ماجستير

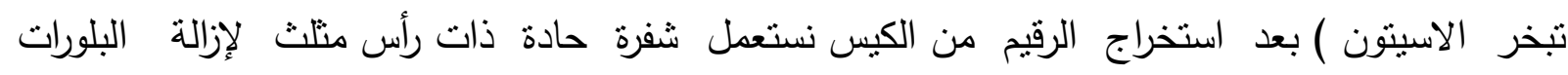

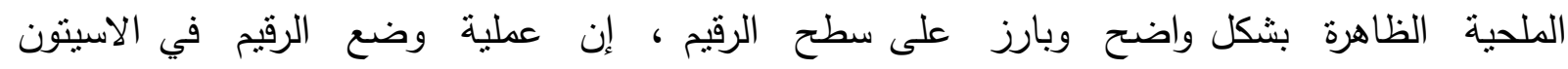

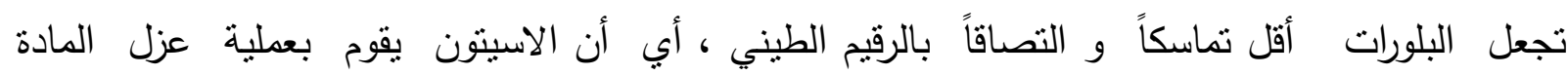

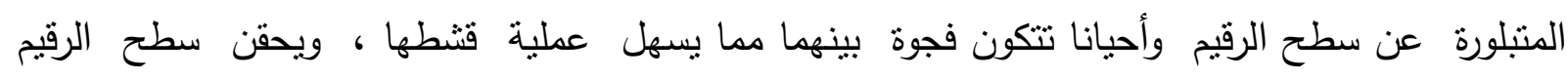

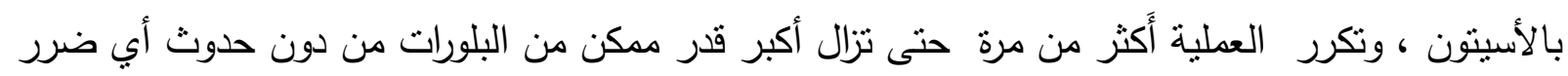

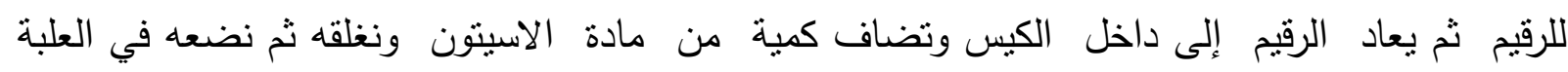

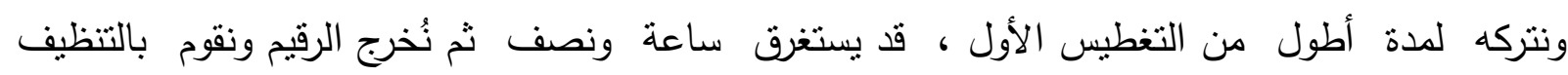

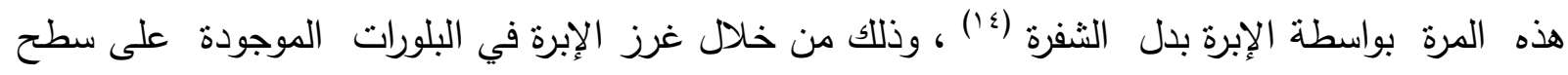

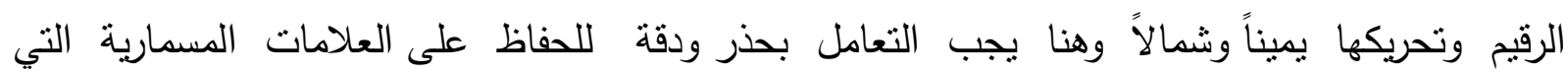

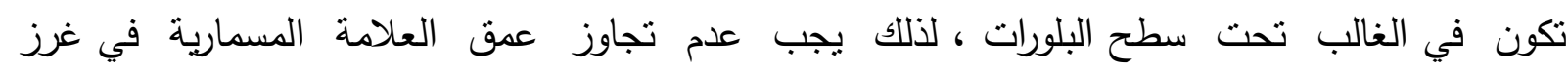

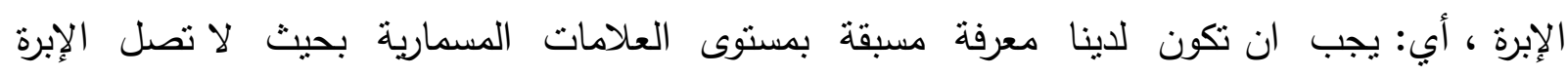

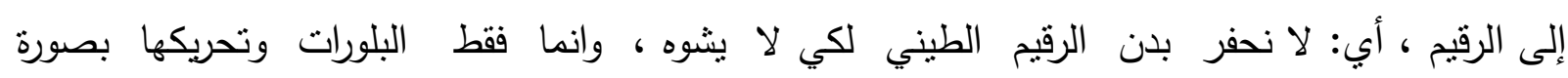

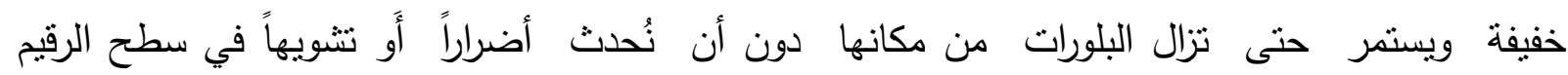

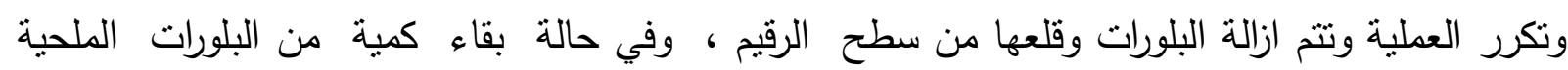
الدقيقة داخل العلامات المسمارية علينا معالجتها في خطوة لاحقة لهذه العملية أب في الخطوة الثالثة .

\section{الخطوة الثالثة :}

في هذه الخطوة نقوم باستعمال إبرة أصغر من الأولى لكي يتم التخلص أو إزالة البلورات

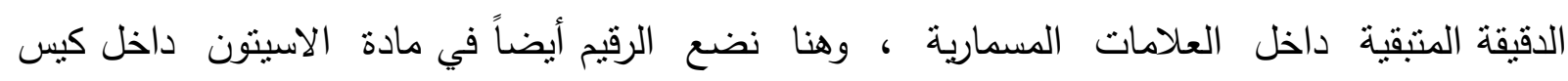

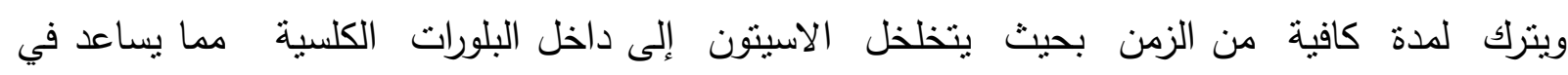

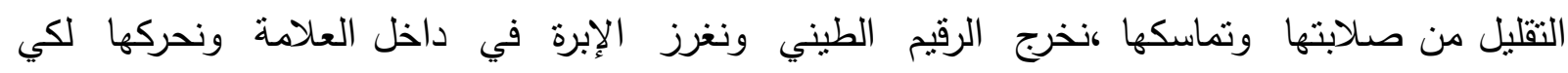

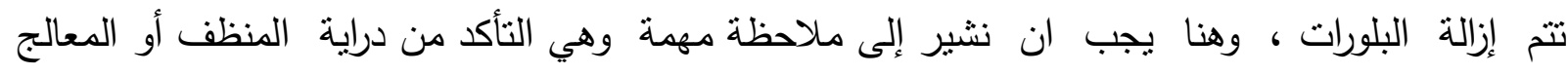

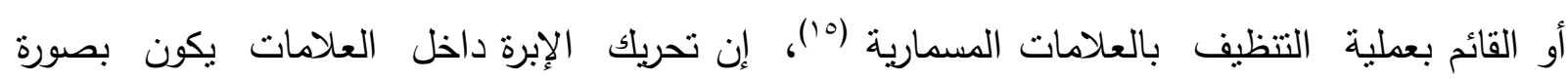

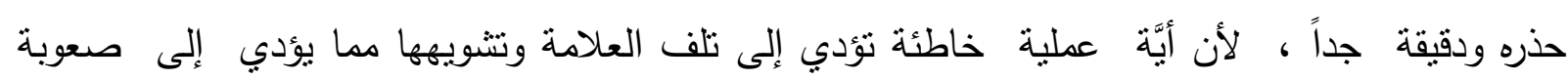

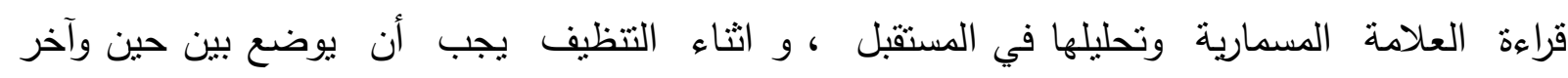

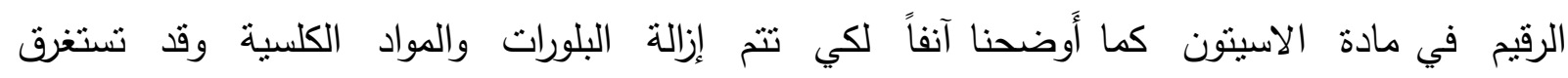

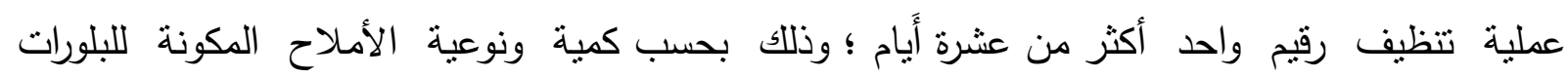




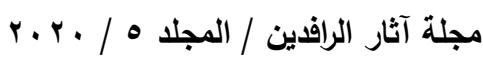

والتكلسات وقد يستغرق يوماً واحداً إذا كانت البلورات قليلة ونوعية الأملاح المكونة لها سريعة

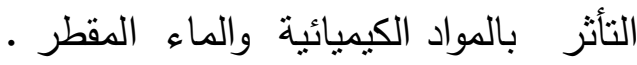

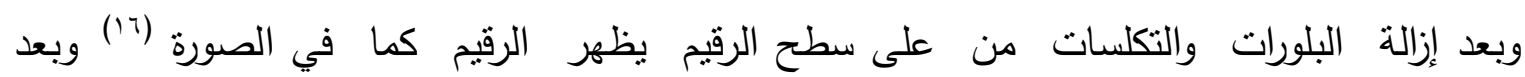

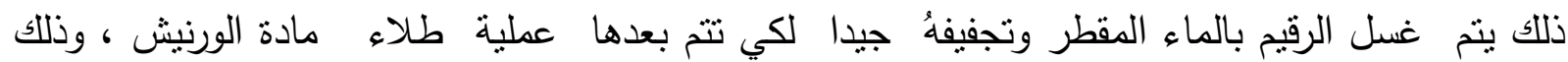

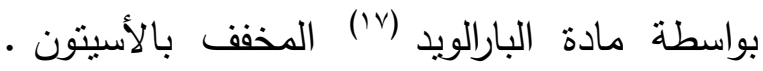

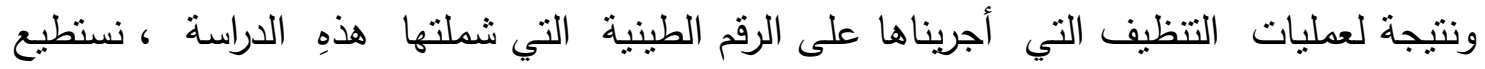

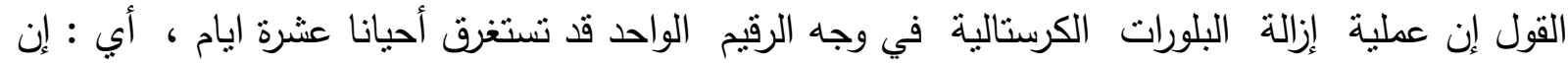

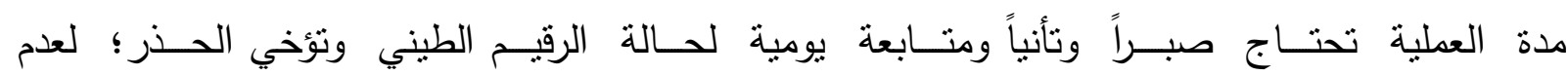
الإضرار به ، لأن بعض عمليات المعالجة قد تكون مضرة بالرقم فبدلاً من إزالة الثوائب والاتربة

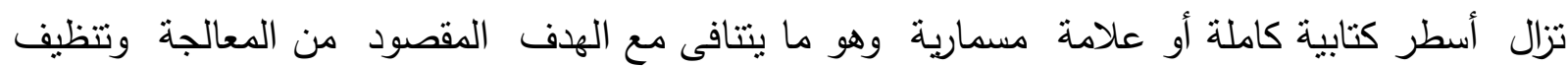

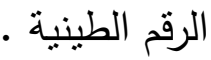

\section{أدوات معالجة الرقم الطينية :}

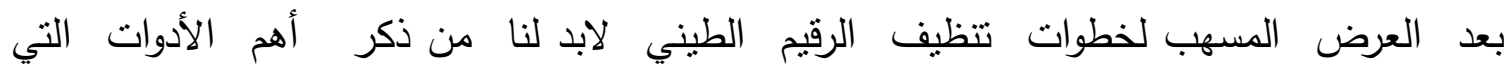

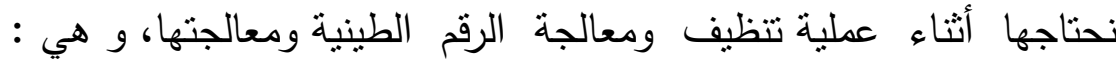

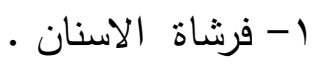

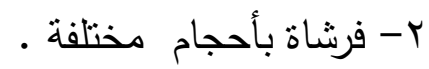
ب- الثناش الطبي للترطيب ورفع الأوساخ والاملاح وكذللك للتجفيف.

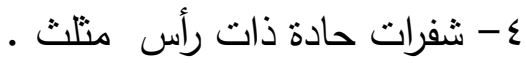
0- المحاليل المستعملة في عملية تنظيف الرقم الطينية :أ- الماء المقطر ب- محلول الاسيتون المركز ( حيث يتم تخفيفه بالماء المقطر بحسب الحاجة ). ج- محاليل كحول(الميثانول).

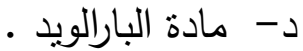


أ. خالد سالم اسماعيل

معالجة رُقُقُ طينية من متحف السليمانية

هجار محمد احمد- طالب ماجستير

Obv.

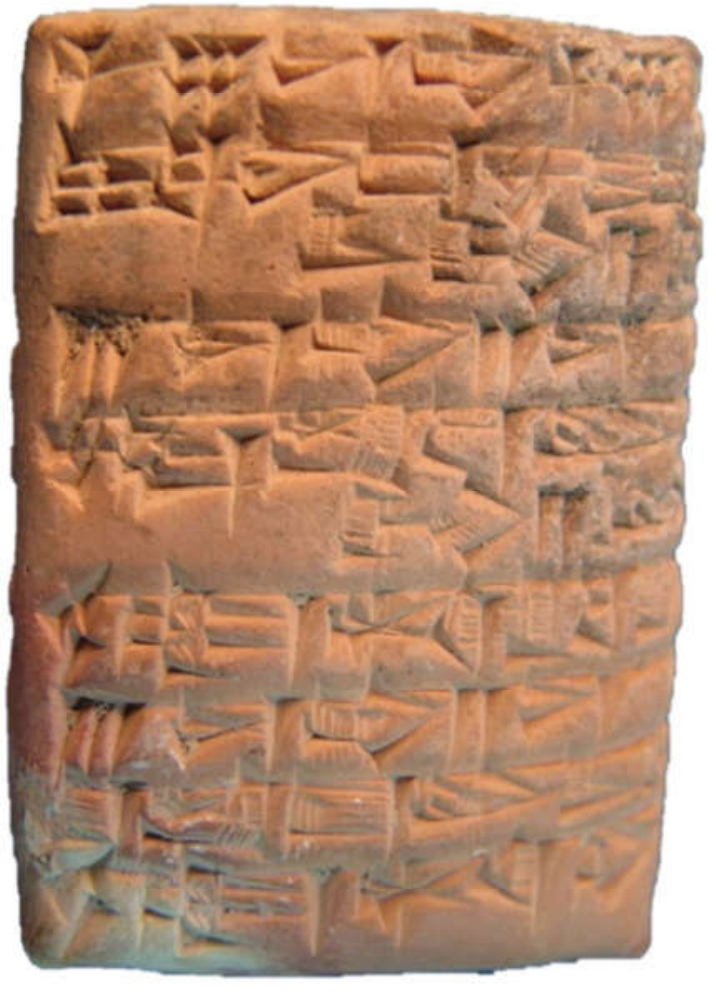

الشكل (1) : صورة لوجه النص الموسوم بالرقم المتحفي ( SM.4644) قبل التظظف. 


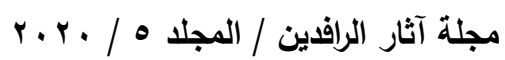

Obv.

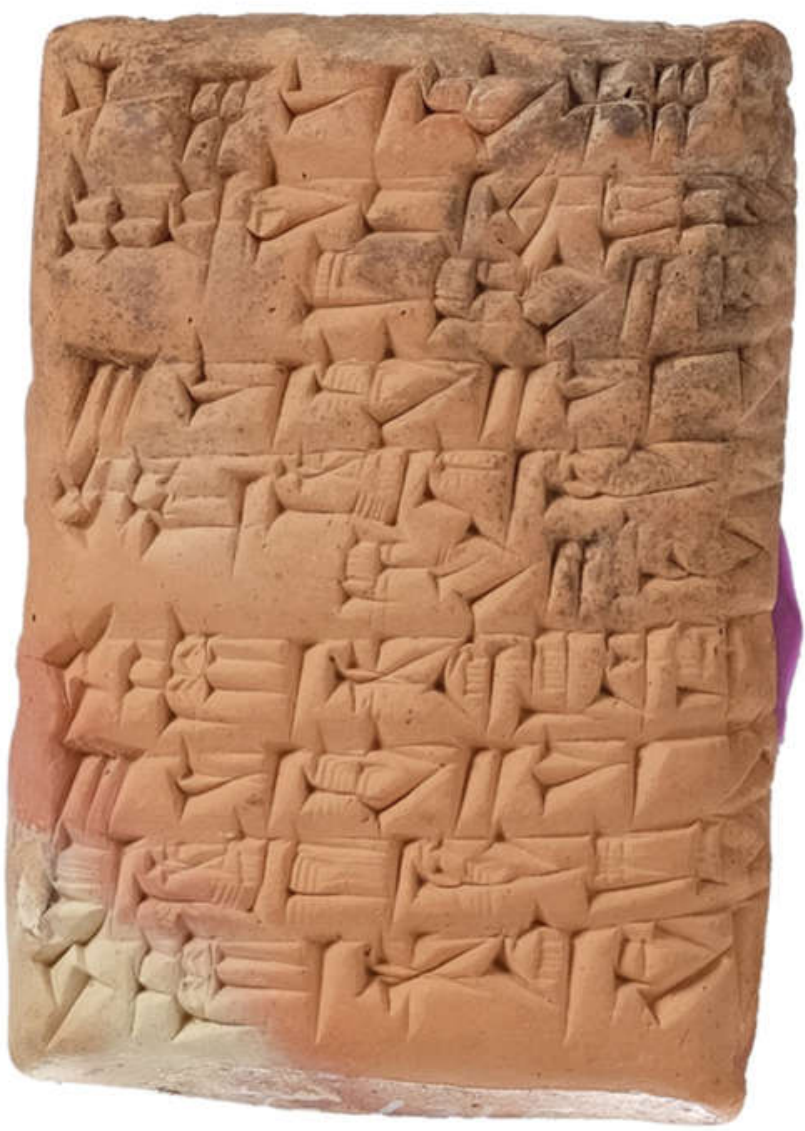

الثكل (r) : صورة لوجه النص الموسوم بالرقم المتحفي (SM.4644) بعد التنظيف. 


$$
\text { هجار محمد احمد - طالب ماجستير }
$$$$
\text { معالجة رُقُم طينية من متحف السليمانية }
$$

Rev.

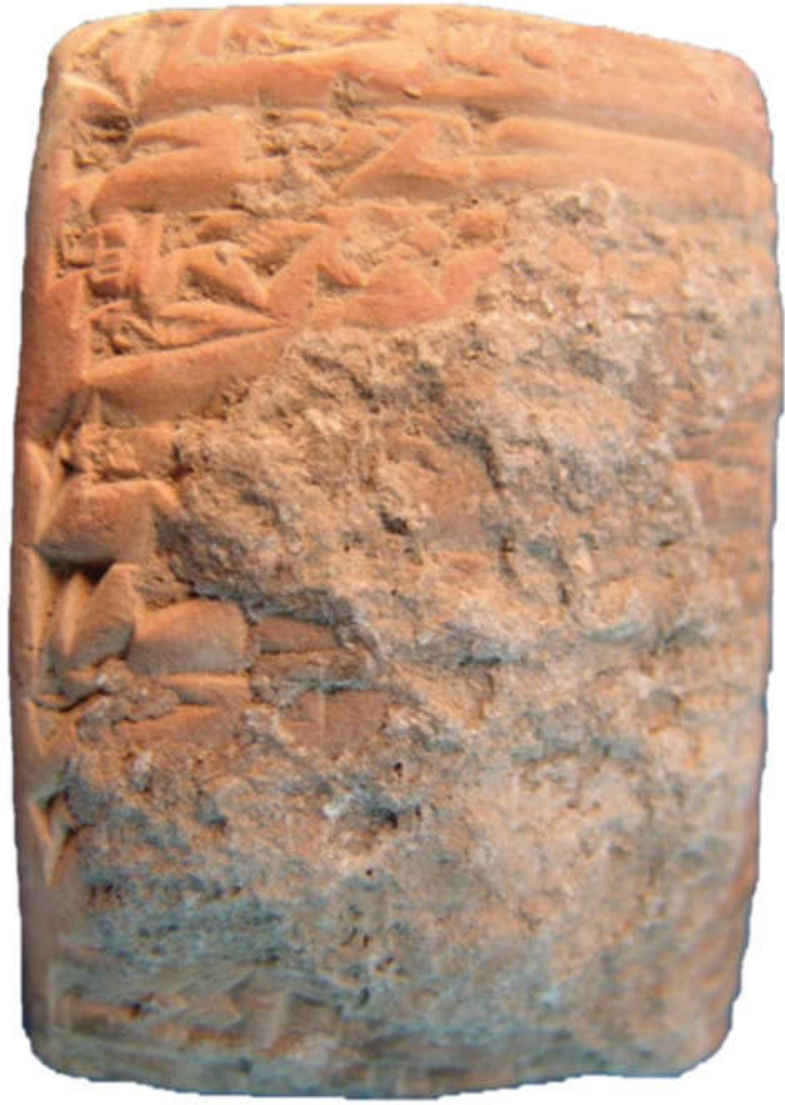

الثكل (ب) : صورة لقفا النص الموسوم بالرقم المتحفي (SM.4644) قبل التظظيف. 


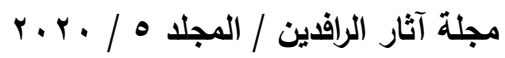

Rev.

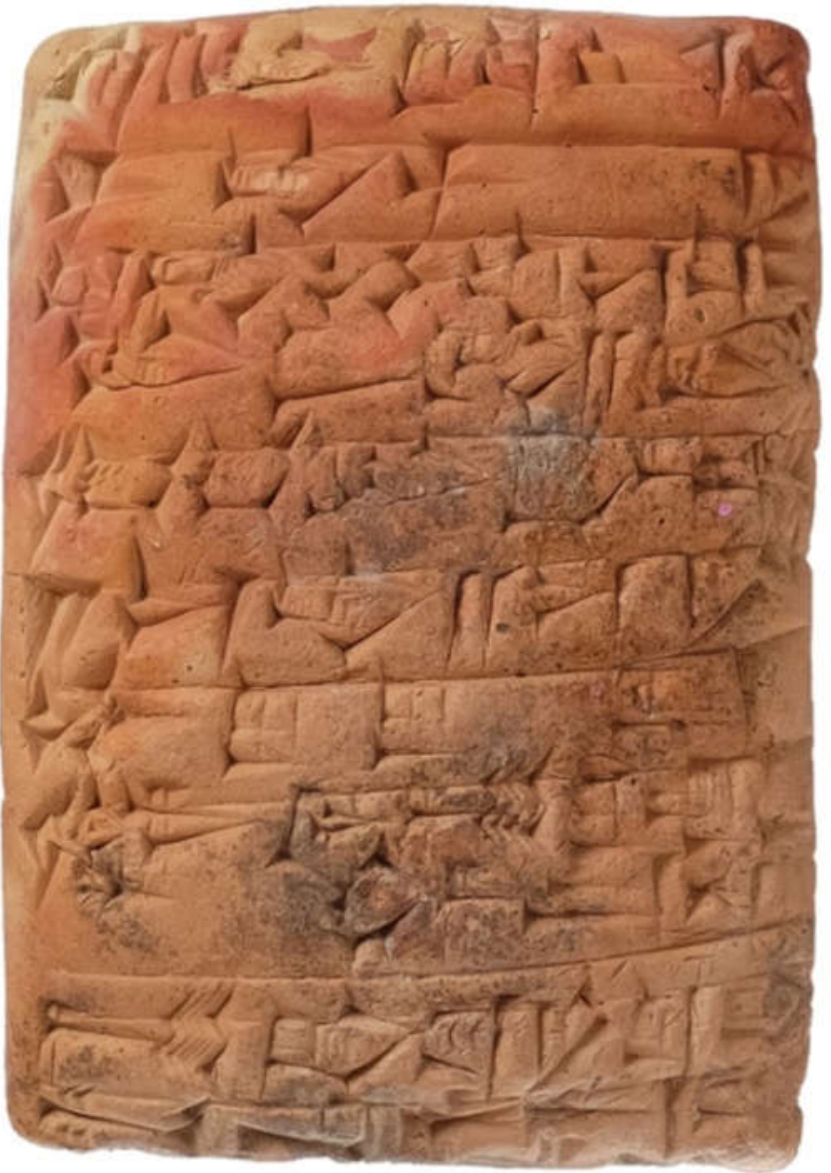

الثكل (ع) : صورة لقفا النص الموسوم بالرقم المتحفي (SM.4644) بعد التتظيف . 


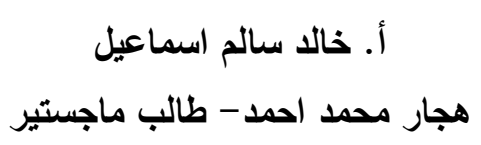$$
\text { معالجة رُقُمُ طينية من متحف السليمانية }
$$

Obv.

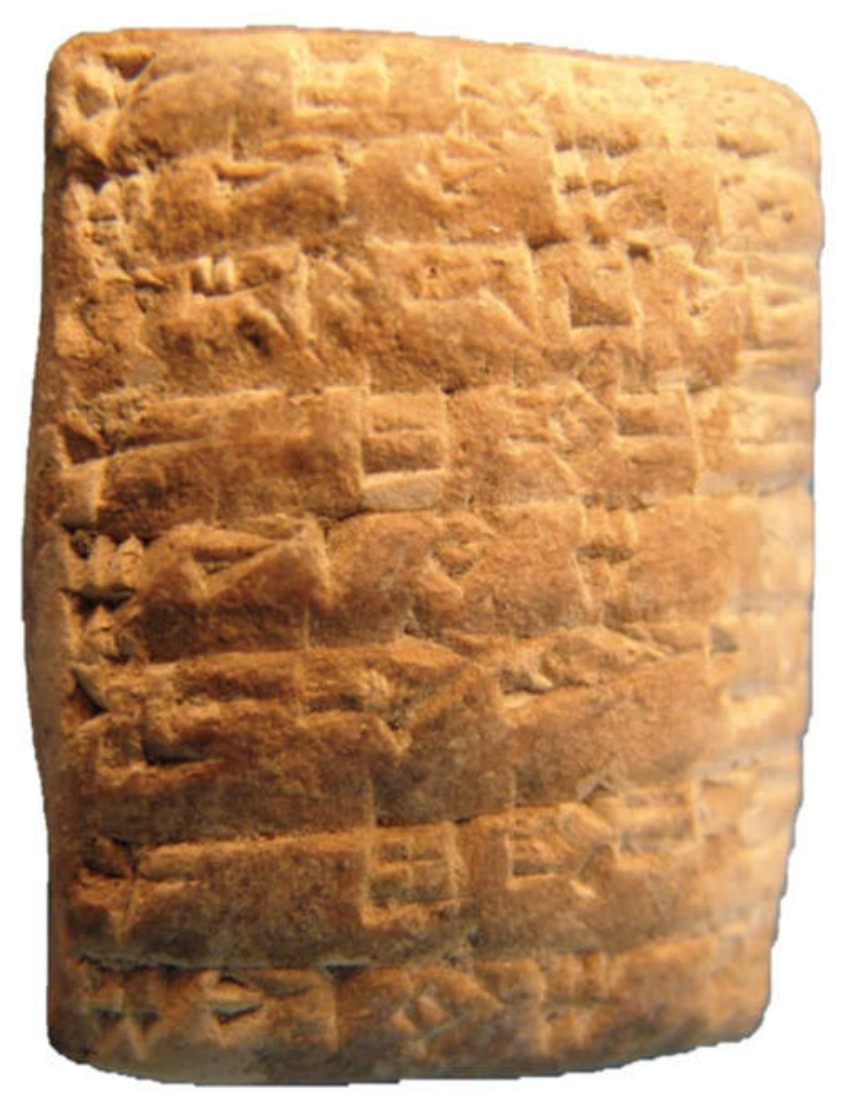

الثكل (0) : صورة لوجه النص الموسوم بالرقم المتحفي (SM.4650) قبل التنظيف . 


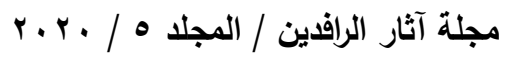

Obv.

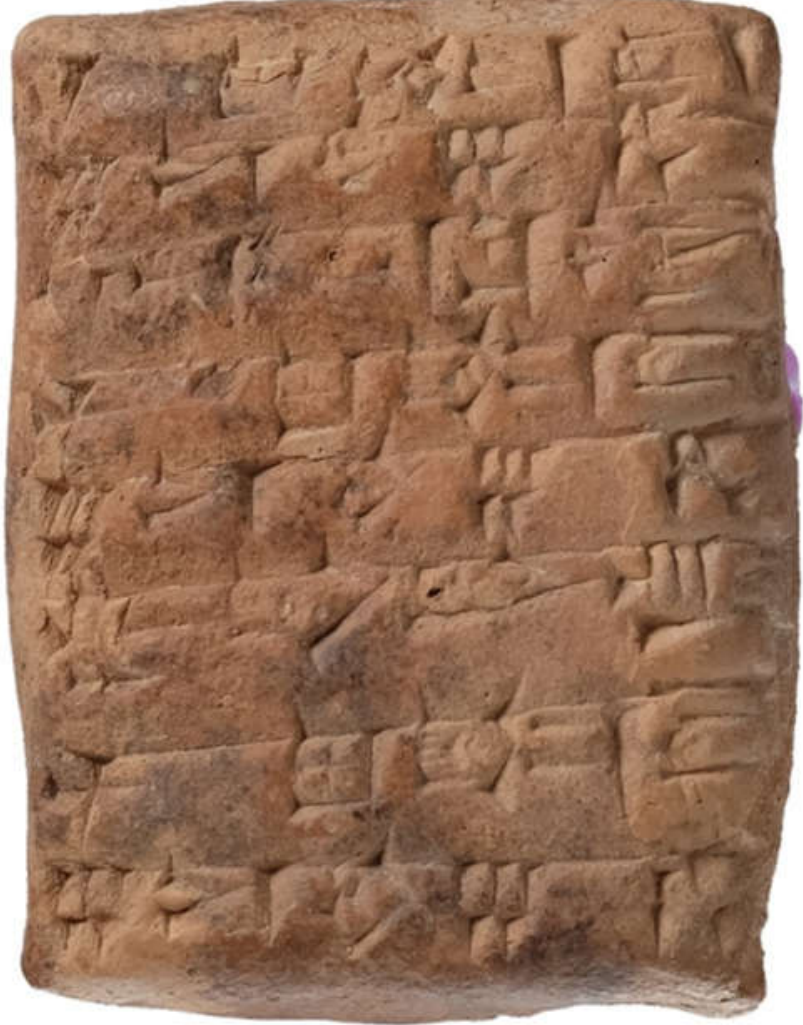

الثكل (T) : صورة لوجه النص الموسوم بالرقم المتحفي (SM.4650) بعد التظظيف . 


$$
\text { هجار محمد احمد - طالب ماجستير }
$$$$
\text { معالجة رُقُقُ طينية من متحف السليمانية }
$$

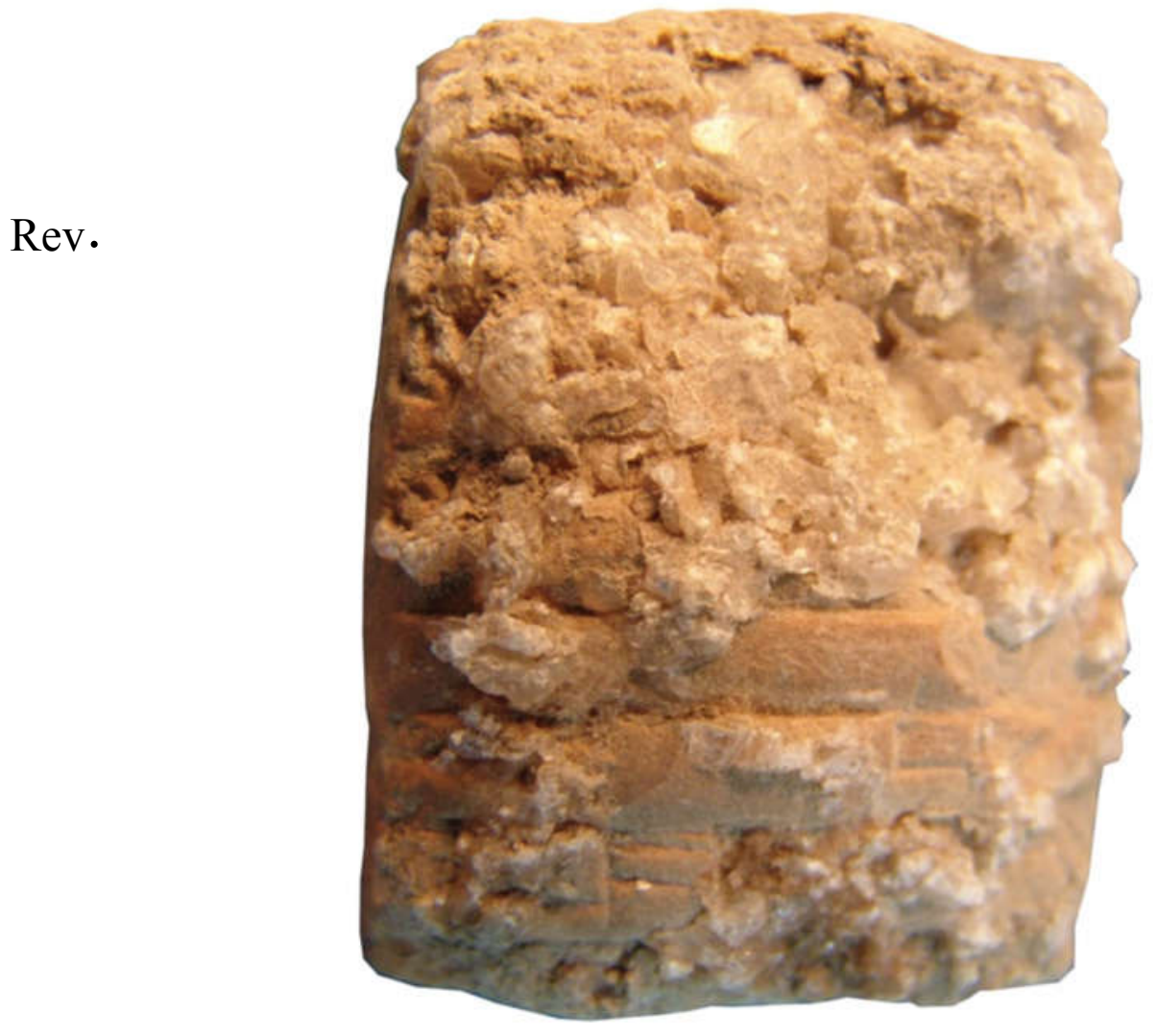

الشكل (V) : صورة لققا النص الموسوم بالرقم المتحفي (SM.4650) قبل التظيف . 


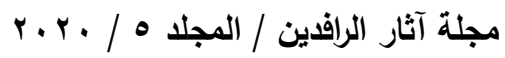

Rev.

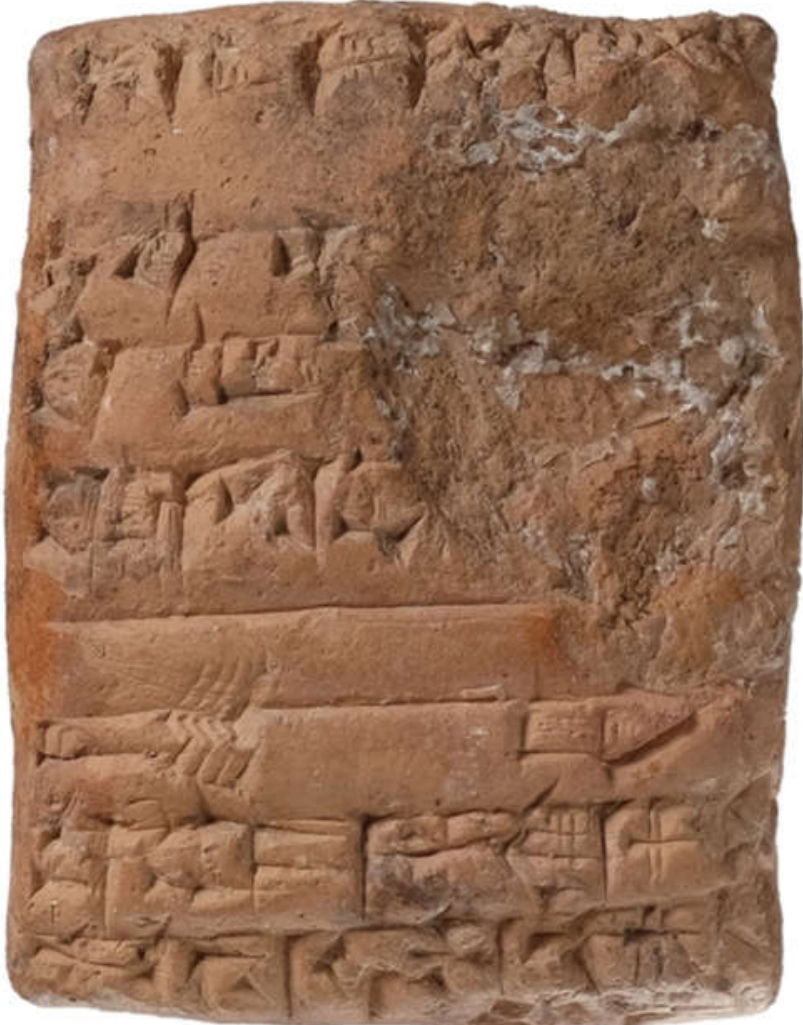

الثكل (^) : صورة لقفا النص الموسوم بالرقم المتحفي (SM.4650) بعد التنظيف 


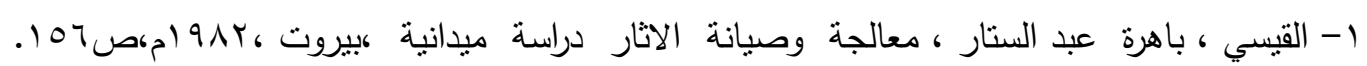

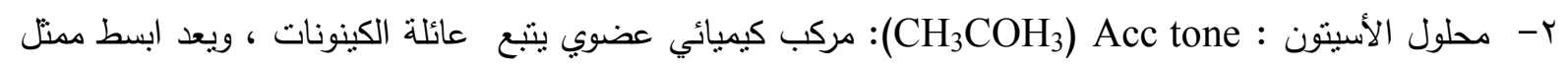

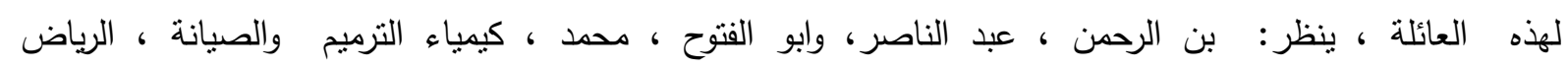

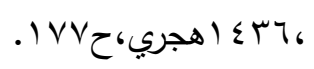
ب- محلول الكحول (الغول) : وهو الاسم العربي لما تعارف عليه الكثيرون بالكحول (Alcohal) ومنها كحول الاثيلي . (c $\left.\mathrm{c}_{2} \mathrm{H}_{3} \mathrm{coH}\right)$

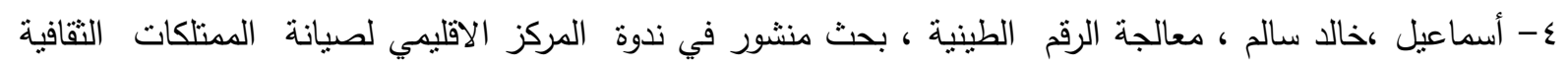

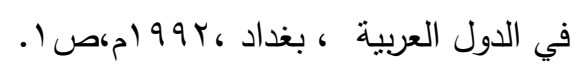

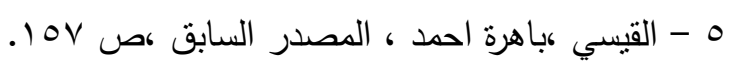

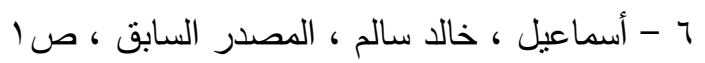

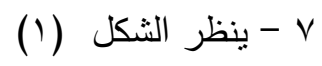

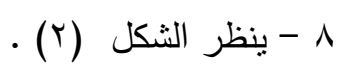

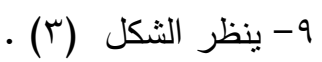

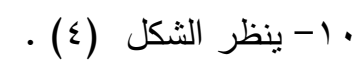

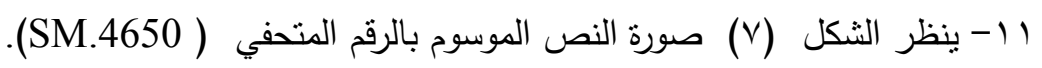

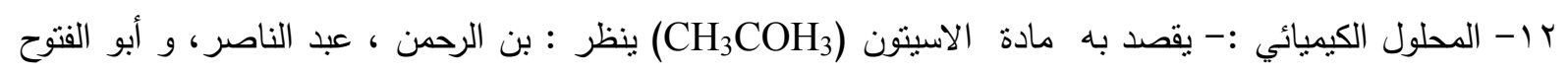

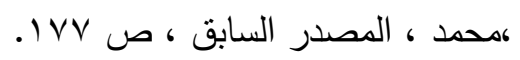
r ا - ينظر الثكل (V) للنص المرقم (SM.4650). ع ا - إن استعمال الثفرة يكون فقط لإزالة البلورات البارزة في المرحلة الأولى من عملية التغطيس .

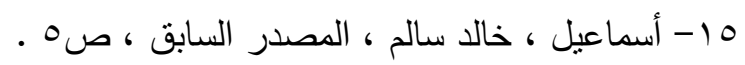

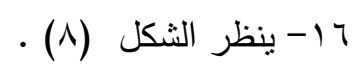
V ا - مادة صمغية حافظة تستعمل في المعالجة والحفظ بوصفها نوعاً من الطلاء واسمها العلمي (Paraloid B-72). 



\section{Journal}

\section{AL- Rafedain Archaeology}

Accredited Scientific Journal

It Search's in Archaeology of Iraq and Ancient Near East

Published by College of Archaeology - University of Mosul

$$
\text { E_Mail:ali_aljuboori@yahoo.com }
$$



